\title{
MEGACRYSTS AND DEFORMED NODULES FROM THE JAGERSFONTEIN KIMBERLITE PIPE
}

\author{
J.J. HOPS, J.J. GURNEY AND B. HARTE*
}

Department of Geochemistry, University of Cape Town, South Africa

${ }^{*}$ Grant Institute of Geology, University of Edinburgh, Scotland

The Jagersfontein kimberlite is a Group 1 kimberlite (Smith, 1984), which hosts abundant deformed peridotite nodules as well as discrete nodules belonging to the Cr-poor megacryst suite. As such it provides an opportunity to evaluate the possible association between the deformed nodules and the Cr-poor megacrysts from a single locality.

Deformed nodules at Jagersfontein can be classified as porphyroclastic or mosaic-porphyroclastic in terms of the classification of Harte (1977). Olivine and orthopyroxene are always the dominant modal phases, with minor amounts of garnet and clinopyroxene. No primary phlogopite, amphibole or spinel is found in these nodules.

Major element mineral chemistry of the deformed peridotites shows that they are generally homogenous. However, the garnets occasionally have rims that are enriched in $\mathrm{FeO}, \mathrm{TiO}_{2}$ and $\mathrm{Na}_{2} \mathrm{O}$ and depleted in $\mathrm{Cr}_{2} \mathrm{O}_{3}$ relative to the grain cores.

Porphyroclast and neoblast compositions are usually not distinguishable from each other, but some of the orthopyroxene neoblasts are enriched in $\mathrm{Al}_{2} \mathrm{O}_{3}, \mathrm{CaO}$ and $\mathrm{Cr}_{2} \mathrm{O}_{3}$

relative to the porphyroclasts, suggesting a hotter environment of equilibration.

The Cr-poor megacryst suite at Jagersfontein is represented, in order of decreasing abundance, by garnet, subcalcic clinopyroxene, olivine, orthopyroxene and phlogopite. A significant difference from other documented megacryst localities is the absence of ilmenite and ilmenite-silicate intergrowths. Zircon is also absent.

The megacrysts are homogenous with respect to their major element mineral chemistry and $\mathrm{c}$ an be distinguished chemically from the minerals in the deformed nodules. The chemical trends defined by the Cr-poor megacrysts are consistent with their derivation by high pressure crystallization of a fractionating melt.

$\underline{\text { Table } 1}$

Range of chemical parameters of megacrysts and deformed peridotites

$$
\begin{array}{llll}
\mathrm{Ca} / \mathrm{Ca}+\mathrm{Mg} \mathrm{Mg} / \mathrm{Mg}+\mathrm{Fe} & \mathrm{TiO}_{2} & \mathrm{Cr}_{2} \mathrm{O}_{3} & \mathrm{Na}_{2} \mathrm{O} \\
(\mathrm{wt} \%) & (\mathrm{wt} \%) & (\mathrm{wt} \%)
\end{array}
$$

\section{GARNET}

Megacryst

Lherzolite

Harzburgite

CLINOPYROXENE

Megacryst

Lherzolite

$30-37$

$36-43$

\section{$85-88$}

89-92

ORTHOPYROXENE

Megacryst

Harzburgite

$1.8-2.9$
$1.8-2.5$
1.9

$83-89$
$91-93$
92
$.1-.25$
$.05-.2$
n.d.

10.1-10.9

$1.4-2.6$

OLIVINE

Megacryst

Lherzolite

Harzburgite

$85-87$

89-92

92
$.4-1.2$

$1.7-6.5$

$.1-\quad .4$

$.6-1.6$

$1.1-2 \cdot 3$

$$
\begin{aligned}
& .07-.14 \\
& .04-.13 \\
& \text { n.d. }
\end{aligned}
$$

$\begin{array}{cc}<.1 & .2-.4 \\ .1-.4 & .1-.3 \\ .34-.36 & \text { n.d. }\end{array}$

$*_{\mathrm{n} \cdot \mathrm{d} .}=$ not detected 
Garnet megacrysts display a wide range in $\mathrm{Mg} / \mathrm{Mg}+\mathrm{Fe}$ and have restricted $\mathrm{Ca}$ concentration. In contrast, garnets from the deformed peridotites are more magnesian and have a range in $\mathrm{Ca}$ concentration. Subcalcic clinopyroxene megacrysts are $\mathrm{Ca}-$ poor and Fe-rich in comparison with the clinopyroxenes from the deformed peridotites. Olivine and orthopyroxene megacrysts are Fe-rich in comparison with olivine and orthopyroxene in the deformed peridotites. The megacrysts are also distinguished by being $\mathrm{Cr}$-poor with respect to the corresponding minerals in the deformed peridotites. Ranges in mineral chemistry are presented in Table 1.

The deformed peridotite nodules yield calculated equilibration temperatures, using the thermometer of Bertrand \& Mercier (1986), in the range 1144 to $1341{ }^{\circ} \mathrm{C}$. There is an apparent correlation between temperature of equilibration and texture, in that the nodules at the low temperature end of this range are porphyroclastic whereas those at higher temperatures are mosaic-porphyroclastic. Temperature calculations using the Bertrand \& Mercier (1986) thermometer require mineral compositions for coexisting clinopyroxene and orthopyroxene, which render it an unsuitable thermometer for the megacryst suite because, although certain clinopyroxene and orthopyroxene megacrysts may well be in equilibrium, coexisting silicate phases are rare. However, based on the results of a comparative study on the deformed nodules, the temperatures obtained using the Lindsley \& Dixon (1976, $20 \mathrm{kbar}$ ) or Boyd \& Nixon (1973) thermometers, which require only clinopyroxene or orthopyroxene compositions respectively for the temperature calculations, are essentially equivalent to those obtained using Bertrand \& Mercier (1986). This suggests comparison between equilibration temperatures obtained using the different thermometers may be valid.

Temperature estimates for the discrete subcalc ic clinopyroxene megacrysts, using the thermometer of Lindsley \& Dixon $(1976,20 \mathrm{kbar})$, are in the range 1314 to $1442{ }^{\circ} \mathrm{C}$. Subcalcic clinopyroxene megacrysts with garnet inclusions have temperatures in the range 1316 to $1471{ }^{\circ} \mathrm{C}$, and garnet megacrysts with clinopyroxene inclusions have temperatures in the range 1297 to $1413{ }^{\circ} \mathrm{C}$. Orthopyroxene megacrysts yield equilibration temperatures, using the empirical thermometer of Boyd \& Nixon (1973), in the range 1190 to $1340{ }^{\circ} \mathrm{C}$.

Calculated equilibration pressures for the deformed peridotites, using the barometer of Nickel \& Green (1985), are essentially isobaric at $50+2$ kbar. Pressure calculations using the Nickel \& Green (1985) barometer require mineral compositions for coexisting garnet and orthopyroxene. Only one garnet megacryst with coexist ing orthopyroxene was found, tie-lines were drawn parallel to this coexisting pair from high, intermediate and low temperature discrete orthopyroxene megacrysts to garnet megacrysts and these were then assumed to be in equilibrium. Pressure estimates obtained for these megacrysts are essentially isobaric at $52 \pm 1 \mathrm{kbar}$. This suggests that the deformed peridotites and the megacrysts have equilibrated at essentially similar depths. The large range of temperatures associated with this isobaric pressure reflects a thermal perturbation of the steady-state continental geotherm by an igneous event.

Petrographically similar polyminerallic inclusions are found in garnet megacrysts as well as in garnets from some deformed nodules. These inclusions consist of serpentine, phlogopite, amphibole, aluminous spinel, aluminous clinopyroxene and aluminous orthopyroxene. Similar inclusions have been interpreted by Schulze (1985) as representing high pressure liquids from which the discrete nodules crystallized. However, it is possible that these inclusions represent a secondary product resulting from reaction between garnet and a metasomatic liquid, possibly of kimberlitic affinity.

The spatial association between the deformed nodules and a pegmatitic phase as proposed by Ehrenberg $(1979,1982$ ) and Harte \& Gurney (1981) appears to be substantiated by this study of megacrysts and deformed nodules from Jagersfontein. 
BERTRAND P. and MERCIER J-C.C. 1986. The mutual solubility of coexisting ortho and clinopyroxene: towards an absolute geothermometer for the natural system. Tectonophysics $70,85-113$.

BOYD F.R. and NIXON P.H. 1973. Origin of the ilmenite-silicate nodules in kimberlites from Lesotho and South Africa. In Nixon P.H. ed, Lesotho Rimberlites, pp 254268. Lesotho National Development Corporation, Maseru.

EHRENBERG S.N. 1979. Garnetiferous ultramafic inclusions in minette from the Navajo volcanic field. In Boyd F.R. and Meyer H.O.A. eds, The Mantle Sample, pp 330-344. American Geophysical Union, Washington.

EHRENBERG S.N. 1982. Petrogenesis of garnet lherzolite and megacrystalline nodules from the Thumb, Navajo volcanic field. Journal of Petrology 23, 507-547.

HARTE B. 1977. Rock nomenclature with particular relation to deformation and recrystallisation textures in olivine-bearing xenoliths. Journal of Geology $85,279-288$.

HARTE B. and GURNEY J.J. 1981. The mode of formation of chromium-poor megacryst suites from kimberlites. Journal of Geology 89, 749-753.

LINDSLEY D.H. and DIXON S.A. 1976. Diopside-enstatite equilibria at $850-1400{ }^{\circ} \mathrm{C}$, 5-35 kbar. American Journal of Science 276, 1285-1301.

NICKEL K.G. and GREEN D.H. 1985. Empirical geothermobarometry for garnet peridotites and implications for the nature of the lithosphere, kimberlites and diamonds. Earth and Planetary Science Letters 73, 158-170.

SCHULZE D.J. 1985. Evidence for primary kimberlitic liquids in megacrysts from kimberlites in Kentucky, U.S.A. Journal of Geology 93, 75-79.

SMITH C.B. 1984. Rubidium-strontium, uranium-lead and samarium-neodymium isotopic studies of kimberlite and selected mantle-derived xenoliths. Unpub. Ph.D., University of Witwatersrand. 